\title{
ENVIRONMENTAL QUALITY COSTS AND THEIR ROLE IN STRATEGIC DECISION MAKING: EVIDENCE FROM IRAQ
}

\author{
Hanan Sahbat Abdullah ${ }^{19}$, Akram Khashea Bediwi ${ }^{20}$, Hakeem \\ Hammood Flayyih ${ }^{21}$
}

\begin{abstract}
The adoption of cost-effective economic units depends on the awareness and understanding of their administrations in taking positive attitudes and internal advocacy to include environmental costs in decision making, as well as allocating costs to products, all this will contribute to the success of managing the economic unit and achieving its objectives in society due to the interrelation of the environmental management cost and the products design management and the environmental management. A questionnaire was distributed to a sample of 55 specialists in this field. The results show that there is a mutual effect between environmental quality costs and the strategic decision making. These decisions, taken in the light of the environmental quality costs, are more accurate and they enable the higher management to reach better strategic decisions, and environmental cost management improves the environmental performance of the economic unit. The lack of commitment of economic units to the standards of environmental pollution leads to damage to the environment and natural resources. It has been recommended to increase the efforts of government agencies to combat pollution and follow-up economic units on an onging basis and impose fines.
\end{abstract}

KEY WORDS: environmental quality costs, strategic decisions

JEL:M41

UDC: 005.52:005.33]:502/504(567) 005.52:330.133.1

COBISS.SR-ID 272198156

\footnotetext{
${ }^{19}$ Department of Accounting, College of Administration and Economics, University of Baghdad, Iraq,e-mail: Drhanan@codec.uobaghdad.edu.iq

${ }^{20}$ Department of Accounting, College of Administration and Economics, University of Baghdad, Iraq, e-mail:akramkashaa@yahoo.com

${ }^{21}$ Lecturer at Department of financial and Banking Sciences, College of Administration and Economics, University of Baghdad, Iraq,e-mail: hakeem.hmood@coadec.uobaghdad.edu.iq
} 


\section{INTRODUCTION}

The relationship between man and the environment began from the time of creation, and has been characterized throughout history as a balanced, peaceful and natural relationship, and they do not pose any threat to each other. It continued until the beginning of the twentieth century, characterized by the industrial revolution and an increase in the mechanization needs demanding more resources and producing many waste and harmful products. (on ground, sea, and air), and with the doubling of human numbers, which can be described as population explosion, increasing demand rates, consumption levels and pushing their aspirations to demand more and more goods and services; this has imposed new global methodologies devoted to an intensive search for more advanced technology to support production to the maximum extent possible. The end of the twentieth century witnessed prosperity and expansion of industrial and agricultural activities in harmony with the increase in demand and population growth; which was met by a serious increase in the quantity and quality of waste and industrial waste that exceeded the capacity of the environment to contain and transform them into harmless decomposing rubbish. Here the balance between the environment and people began to lose stability, people began to worry about the danger inherent in the piles of these wastes and their negative effects that threaten their existence and future, and at the end of the twentieth century the idea of sustainable development started to entrench (Mreza, Bachay \& Flayyih, 2018).

The problem of environmental pollution in many countries of the world threatens the continuity of human life, and the economic units started spending large amounts of money to reduce and control environmental pollution. Taking care of the environment is one of the most important issues of concern to developing countries in recent times as well as developed countries, and part of the budgets of these countries is dedicated to the protection and preservation of the environment from the serious effects triggered by pollutants which are produced by industrial processes and technology. On this ground, the economic units should contribute economically to the improvement of the environment quality level. The success of the economical units in the long run will depend on their ability to balance future growth and preserve the natural environment. These units should therefore take into account the elements of environmental quality costs in determining and evaluating their operations and charging environmental costs to the cost of production. Therefore, environmental quality costs will play an important role in changing the behavior of strategic decision-makers and individuals concerned with the future of economic units, preserving the environment and working to increase profits and achieve competitive advantage via making the right decisions. This study attempts to analyze the impact of environmental quality costs in improving the accuracy of strategic decisions.

\section{LITERATURE REVIEW}

Several studies have gone through the topic of the environmental quality costs and the strategic decisions and have dealt with them as variables isolated from each other, one of these studies is that of (Papadakis, Lioukas \& Chambers, 1998) which examined the relationship between strategic decision-making and the management of economic unit operations. By analyzing the processes through which decisions are made, these processes are rational comprehensiveness, financial reporting, formalization of rules, hierarchical decentralization, and lateral communication. The study stressed the importance of strategic decisions and the very fact that they are formed in all these categories by a number of factors.

The study of (Stokman, Van Assen, Van der Knoop and Van Oosten, 2000) discussed the methodology of collective and joint intervention in strategic decision-making. This study proved that the long-term vision in strategic decision-making can be obtained by analyzing the problem 
correctly. As for Carpenter \& Westphal's study (2001), it examined how to determine the board's ability and the impact of members of the Board of Directors of economic units over the importance of results and the contribution to strategic decision-making. While Sarkis' study (2003) examined the strategic decision framework for green supply chain management, this relationship provides a strategic decision framework showing the way it affects on management decisions. This study focuses on the components and elements of green supply chain management and emphasizes the integration of environmental nature into strategic and operational decisionmaking in order to obtain or maintain competitive advantage. The study carried out by Alcouffe, Berland, Dreveton \& Essid (2010), addressed a close exploration of environmental accounting literature and of the cost guides in studying the nature and the role of environmental cost engines. which is one of the goals identified by Gray et al (1993), namely, self-determining of the environmental costs and environmental incomes outside the traditional financial accounting system. More specifically, the aim was to identify cost drivers to highlight the complexity of the process of integrating environmental costs.

A study done by (Ahmed \& Omotunde, 2012) investigated the theories and strategies for good decision-making. The theories and strategies that can help in making good decisions should be understood. The study emphasized that there should be an expertise in strategic decisionmaking and industry. The strategic decision itself is a skill and fundamentally the strategic decisions are taken by managers and officials. Duma's study (Icerli, Yucenursen \& Apak, 2013) investigated an analysis of the environmental costs management within the activity of works to achieve efficiency and effectiveness, and it stresses minimizing environmental damage. It also stressed the possibility of identifying and measuring the environmental costs of activities to be undertaken during the period and reducing environmental costs through environmental management accounting. Elnagy's study (2014) examined how to measure and detect environmental quality costs in the financial statements of economic units, and making use of the results of the analysis and measurement of beneficiaries taking into account the environmental impacts and commitments.

Peterlin, Pearse \& Dimovski's study (2015) dealt with the concepts of the implications of service leadership responsibility and sustainable leadership for strategic decision-making by senior management of economic units. A different type of leadership is needed if effective strategic decisions are made in units that seek to become more sustainable. As for Cao,You \& Liu's study (2017), it examined the use of the beginning of technology to analyze the nonlinear relationship between three types of environmental regulation intensity and technology innovation in manufacturing on the basis of China sub-sector data from 2005 to 2015. Our study is an analysis of the impact of environmental quality costs on strategic decision making done by studying the concept of quality, environmental quality costs and elements of environmental quality costs as well as strategic decisions and the importance of managing environmental costs in strategic decision making and the relationship between environmental quality costs and strategic decision making.

\section{ENVIRONMENTAL QUALITY COSTS}

\section{The Significance of Environmental Cost Accounting}

The idea of environmental costs dates back to the end of the past century when the idea of sustainable development grounded throughout the report of the World Commission on Environment and Development (1987), which was titled "our common future", the topic was developed at the Stockholm Conference in 1974, which spoke for the first time about the concept of sustainable development, followed by the Rio Summit for the first time on environment and sustainable development, the results of which were announced in 1992 concerning the use of 
natural resources in a way that ensures the rights of future generations, requiring the rationalization of economic, social and technological curricula (Mreza, Bachay \& Flayyih, 2018); (Hamdan, Bachay, Flayyih \& Talab, 2018).

In recent years there has been an increasing interest in accounting for environmental costs and the need to use and implement environmental cost accounting procedures more clearly by economic units in order to promote human well-being and to be an important source of information for sustainable development. It has been defined as a business tool that provides basic environmental data for the management of economic units from simple to comprehensive ways linking financial and non-financial information of decision-making (Ismail, et.al, 2014). It is also known as an appropriate tool to ensure legal compliance at lower cost. In another study in 1997, it was confirmed that the use of environmental cost accounting system, oriented to decision making, by economic units could reduce total costs by $5 \%$ (Chandrupatla, Belegundu, Ramesh \& Ray, 2002).

\section{Environmental Quality Concept}

Quality in its general sense means compliance with requirements, i.e., the degree to which performance meets expectations (Chandrupatla, 2009). Environmental quality is intended to preserve the environment components of air, water, soil, plants and animals within the acceptable level by improving air quality, providing clean, high quality water and preparing waste management programs that protect public health and the environment and promote development decisions that respect natural areas in accordance with Pollution standards set by environmental authorities to meet the local, economic and recreational needs of the community and to preserve the health of individuals and property (Ismail, Ramli \& Darus, 2014).

\section{Concept of Environmental Quality Costs}

The environmental costs, both monetary and non-monetary, incurred by the economic unit and resulting from activities that affect environmental quality, are the traditional costs such as buildings, equipment, materials, labor and potential hidden costs identified by the accounting system but subsequently lost in public expenditure, besides, the costs that may be difficult to measure because of emergency units (Shapiro, Stoughton, Graff \& Feng, 2000). EPA defines environmental costs as "those costs that have a direct financial impact on economic unity (internal costs), as well as costs that have an impact on society and the environment (external costs)" (Rakos \& Antohe, 2014.

\section{Elements of Environmental Quality Costs}

Elements of environmental quality costs can be categorized into four categories (Hansen, Mowen \& Guan, 2009):

1. Environmental prevention costs: Costs of activities undertaken to prevent the production of waste or contaminants that can cause damage and pollution to the environment.

2. Environmental Disclosure Costs: The costs of activities performed to detect and determine whether the products, processes and other activities within the economic unit are in accordance with the appropriate environmental standards.

3. Internal failure costs of the environment: Costs of completed and formed activities due to the presence of wastes and pollutants produced by the production processes but not discharged into the environment. Consequently, internal failure costs are taken to eliminate them and manage waste or contaminants as soon as they are formed.

4. Costs of environment external failure: costs of activities carried out after the discharge of wastes and pollutants into the environment. The costs of external failure can be divided into two categories (realized and unrealized). The costs of the realized external 
failure are those costs taken by the unit and paid for. The unrealized costs (social) are caused by economic unity but are taken and paid for by parties outside the economic unit. The costs social failure classify into (1) those costs resulting from environmental degradation and (2) those costs associated with a negative impact on the property or well-being of the individuals. In both cases, costs are borne by others and not by the economic unit. Although the unit caused them to do so.

\section{STRATEGIC DECISIONS}

\section{Concept of Strategic Decisions}

What distinguishes strategic management is its emphasis on the importance of strategic decision-making, which is used to guide economic unit towards achieving its goals. Strategic decisions are made on alternatives that affect key factors determining the success of the economic unit strategy. One of the assumptions of strategic decision-making is that individuals should make decisions with the most rationality possible. Individuals often make these decisions by identifying and comparing options to determine which ones give the optimal outcome to a particular set of circumstances (Vasilescu, 2011). One of the characteristics of strategic decisions is the responsibility of senior management. It reflects the interaction between economic unit and its environment and explain how to manage this relationship (Elbanna, 2006). Costs taken by the economic unit to comply with the environmental laws are clearly environmental costs. Environmental remediation costs, pollution control equipment, non-compliance penalties, and other costs spent on environmental protection are undoubtedly among the environmental costs (ICF \& EPA, 1995).

\section{RESEARCH METHODOLOGY}

In light of the lack of control over environmental waste due to the absence of accounting standards and practices governing these practices in the financial statements, in order to deal with them financially by taking the necessary measures to reduce these pollutants, this study tries to shed light on the role of environmental quality costs in the process of strategic decisions- making at the level of economic units in order to determine the impact of those costs on these decisions, so this research seeks to test the following hypothesis:

1. "There is a statistically significant relationship between environmental quality costs and strategic decision making".

The following hypotheses are derived from this hypothesis:

1. "There is a significant correlation with statistical indications between the costs of environmental quality and strategic decision making."

2. "There is a significant impact relationship with statistical indications between environmental quality costs in strategic decision making."

In order to test this hypothesis, a questionnaire has been designed. The research community is composed of academics and specialists in charge of cost accounting for their experience and expertise in accordance with the requirements of the questionnaire. A questionnaire was prepared according to Likart's Five-Dimensional Scale in order to test the answers of a sample of the research community in Iraq. It included (22) questions distributed on two axes. Table (1) shows the educational achievement of the study sample. 
Table 1: Number and Percentage of Sample Sex Study of the analyzed Questionnaires

\begin{tabular}{|c|c|c|c|}
\hline Education Background & Male & Female & Total \\
\hline Number & 15 & 40 & 55 \\
\hline Percentage & $27.3 \%$ & $72.7 \%$ & $100 \%$ \\
\hline
\end{tabular}

Table 2:Age of the Study Sample

\begin{tabular}{|l|c|c|c|c|}
\hline Expertise & $\begin{array}{c}\text { Less than } 30 \\
\text { years }\end{array}$ & From 30 to 40 years & 41 years and up & 16 years and up \\
\hline Number & 3 & 18 & 34 & 55 \\
\hline Percentage & $5.5 \%$ & $32.7 \%$ & $61.8 \%$ & $100 \%$ \\
\hline
\end{tabular}

Table (2) shows as well the years of the expertise for the study sample.

Table 3: Years of the Professional Expertise of the Study Sample

\begin{tabular}{|l|c|c|c|c|}
\hline $\begin{array}{l}\text { The Professional } \\
\text { Expertise }\end{array}$ & $\begin{array}{c}\text { Less than } 10 \\
\text { years }\end{array}$ & From 10 to 20 years & 21 years and up & Total \\
\hline Number & 12 & 24 & 19 & 55 \\
\hline Percentage & $21.8 \%$ & $43.6 \%$ & $34.5 \%$ & $100 \%$ \\
\hline
\end{tabular}

Table 4. shows the academic status of the study sample.

Table 4: The Academic Status of the Study Sample

\begin{tabular}{|l|c|c|c|c|c|}
\hline \multicolumn{1}{|c|}{ Expertise } & Asst. Lect. & Lect. & Asst. Prof. & Prof. & Total \\
\hline Number & 15 & 24 & 10 & 6 & 55 \\
\hline Percentage & 27.3 & 43.6 & 18.2 & 10.9 & $100 \%$ \\
\hline
\end{tabular}

\section{Results of the Descriptive Tests}

The descriptive statistical tools (arithmetic mean and standard deviation) were used to estimate the absolute dispersion of the responses of the sample members from the mean and the coefficient of variation to estimate the relative dispersion in order to draw a general picture or framework for the preference of the respondents and their general trends in relation to the search variables, this is done through Likart's Five-Dimensional Scale regarding the options and it is an ordinal scale, and the numbers processed by the statistical program (SPSS) stand for (weights), which are: $(5=$ completely agree , $4=$ agree, $3=$ neutral, $2=$ do not agree, $1=$ completely do not agree). The arithmetic mean (weighted mean) of the scale is determined by determining the length of the first period and it equals ( 4 to 5), 4 represents the number of the distances ( from 1 up to 2 the first distance, from 2 up to 3 the second distance, from 3 up to 4 the third distance and from 4 up to 5 the fourth distance), whereas number 5 represents the number of the options and the division of 4 over 5 produces the length of the period (category) and it equals 0.8 and the distribution will be as the following: not fully agreed from 1 to 1.79 , not agreed from 1.8 to 2.59 , neutral from 2.6 to 3.39 , agreed from 3.4 to 4.19 , completely agreed from 4.2 to 5 . The questionnaire consisted of (22) questions, divided into two axises: the first axis included the first (12) questions and the (10) questions for the second axis. Table 5. shows the results of the descriptive tests. 
Table 5:Results of the Descriptive Tests

\begin{tabular}{|r|r|c|c|}
\hline \multicolumn{2}{|c|}{ Variables } & Environmental Quality Costs & Strategic Decision Making \\
\hline \multirow{2}{*}{$N$} & Valid & 55 & 55 \\
\cline { 2 - 4 } & Missing & 0 & 0 \\
\hline Mean & 4.1091 & 4.3091 \\
\hline Std. Deviation & 0.62872 & 0.61982 \\
\hline Result & Agree & Complete Agree \\
\hline
\end{tabular}

Table 5. shows that the arithmetic mean of the environmental quality costs is , the arithmetic mean of strategic decisions is , which is higher than the hypothesized mean which is (3), the standard deviation of environmental quality costs is (62\%), strategic decisions (61\%), Which indicates a high harmony in the answers.

\section{RESULTS OF THE DEDUCTIVE TESTS}

\section{Testing the First hypothesis of the Research}

The second hypothesis of the research stated that:

"There is a significant correlation with statistical indications between the costs of environmental quality and strategic decision making".

Going with the research methodology and to determine the validity of the correlation hypotheses assumed by the research, the Pearson correlation coefficient was used to determine the nature and level of the relationship between the basic search variables and the correlation of this relationship. The first step in determining the nature of the relationship is if we have only two variables, the variable represents the environmental quality costs and it is determined by the researchers. The independent variable is accompanied by another variable called the dependent variable represented by the strategic decisions. It is noted that the relationship between the variables is reciprocal in relation to their interdependence and influence with each other.

Table 6: Correlation Results

\begin{tabular}{|c|c|c|c|}
\hline & Variables & Environmental Quality Costs & Strategic Decision Making \\
\hline & Pearson Correlation & 1 & 0.601 \\
\hline ฮี & Sig. (2-tailed) & & 0.000 \\
\hline 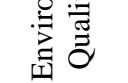 & $\mathrm{N}$ & 55 & 55 \\
\hline.$\approx 00$ & Pearson Correlation & 0.601 & 1 \\
\hline$\frac{0}{0} \cdot \frac{\bar{z}}{\pi}$ & Sig. (2-tailed) & 0.000 & \\
\hline$\stackrel{\Delta}{\Delta} \Sigma$ & $\mathrm{N}$ & 55 & 55 \\
\hline
\end{tabular}

In Table 6., Pearson Correlation coefficient of the relationship between environmental quality costs and strategic decisions is $(0.601)$ with a significance level of $(0.05)$, which is a strong, positive, and significant correlation because the $\mathrm{P}$-value is smaller than the significant level of (0.05), and due to the result the first hypothesis is accepted. 


\section{Regression Test Results}

Testing the second hypothesis of the research:

"There is a significant impact relationship with statistical indications between environmental quality costs in strategic decision making".

The effect relationships were investigated according to the simple regression equation. Table 7. shows that $\left({ }^{2} R=0.36\right)$ indicating that environmental quality costs accounted for $(36 \%)$ of the changes in (strategic decisions), and the ratio (64\%) is due to the contribution of variables other than the ones in the model Regression

\section{Table 7: Model Summary}

\begin{tabular}{|c|c|c|c|c|}
\hline Model & R & R Square & Adjusted R Square & Std. Error of the Estimate \\
\hline 1 & 0.601 & 0.361 & 0.349 & 0.50008 \\
\hline
\end{tabular}

It is clear from Table 8 . that the calculated $F$ value of the model reached $(29,956)$, which is greater than the value of $(\mathrm{F})$ of the scale at the level of significance (0.05), and accordingly we accept the hypothesis, this means that there is a statistically significant impact of (the environmental quality costs) at a significant level of (5\%) with a confidence level of $(95 \%)$ in (strategic decisions). The results of the hypothesis test under P-Value showed that they were statistically significant, being below the level of significance (0.05), indicating that there is an effect of (environmental quality costs) in strategic decisions.

\section{Table 8: ANOVA}

\begin{tabular}{|c|c|c|c|c|c|}
\hline Model & Sum of Squares & $\mathrm{df}$ & Mean Square & $\mathrm{F}$ & Sig. \\
\hline Regression & 7.491 & 1 & 7.491 & 29.956 & 0.000 \\
\hline Residual & 13.254 & 53 & .250 & & \\
\hline Total & 20.745 & 54 & & & \\
\hline
\end{tabular}

Table 9.hows that the slope coefficient of the regression angle is $(\beta=0.59)$ and that any increase in the level of (environmental quality costs) in one unit will improve the strategic decisions by $(59 \%), \beta$ indicates the significance of the parameter and confirm the result of estimating the regression coefficient, i.e., the change in the amount of one unit is due to a corresponding change in the adopted variable of (59\%).

Table 8: Coefficients

\begin{tabular}{|c|c|c|c|c|c|}
\hline \multirow{2}{*}{ Model } & \multicolumn{2}{|c|}{ Unstandardized Coefficients } & Standardized Coefficients & \multirow{2}{*}{ Sig. } & \\
\cline { 2 - 4 } & $\mathrm{B}$ & Std. Error & Beta & & \\
\hline (Constant) & 1.875 & 0.450 & & 4.168 & 0.000 \\
$\mathrm{X}$ & 0.592 & 0.108 & 0.601 & 5.473 & 0.000 \\
\hline
\end{tabular}




\section{RECOMMENDATIONS}

The results show that there is a mutual effect between environmental quality costs and strategic decision making and that these decisions taken in the light of environmental quality costs information are more accurate and enable senior management to reach better strategic decisions. What is more, environmental cost management improves environmental performance of the economic unit. The lack of compliance of economic units with environmental pollution standards causes damage to the environment and natural resources, and the absence of specific criteria to be used in the measurement process may create difficulties for the economic units. The constant increase in these costs leads to a need of setting specific and clear criteria, besides a classification of these costs being accounted for by the economic units. The researchers recommend the existence of clear cut criteria to measure the environmental obligations in the community and that economic units show interest in measuring the costs of environmental quality and should be loaded in the financial statements of the economic units, while working to combat pollution caused by their products. And the necessity to increase the efforts of government agencies to combat pollution and follow-up economic units on an ongoing basis and impose fines. The economic units should also not ignore environmental quality cost information in decision making, especially when making long-term strategic decisions.

\section{REFERENCES}

[1]. Ahmed, M. T., \& Omotunde, H. (2012). Theories and strategies of good decision making. International Journal of Scientific \& Technology Research, 1(10), 51-54.

[2]. Alcouffe, S., Berland, N., Dreveton, B., \& Essid, M. (2010, May). An empirical study of environmental cost drivers. In Crises et nouvelles problématiques de la Valeur (pp. CDROM).

[3]. Cao, Y. H., You, J. X., \& Liu, H. C. (2017). Optimal environmental regulation intensity of manufacturing technology innovation in view of pollution heterogeneity. Sustainability, 9(7), 1240.

[4]. Carpenter, M. A., \& Westphal, J. D. (2001). The strategic context of external network ties: Examining the impact of director appointments on board involvement in strategic decision making. Academy of Management journal, 44(4), 639-660.

[5]. Chandrupatla, T. R. (2009). Quality and reliability in engineering (Vol. 2). New York, NY: Cambridge University Press.

[6]. Chandrupatla, T. R., Belegundu, A. D., Ramesh, T., \& Ray, C. (2002). Introduction to finite elements in engineering (Vol. 2). Upper Saddle River, NJ: Prentice Hall.

[7]. Duma, H., İçerli, M. Y., Yücenurşen, M., \& Apak, İ. (2013). Environmental cost management within the sustainable business.

[8]. Elbanna, S. (2006). Strategic decision-making: Process perspectives. International Journal of Management Reviews, 8(1), 1-20.

[9]. Elnagy, Nasreldeen Gidam, (2014). Measurement and disclosure about costs Environmental quality and its impact on the financial statements published. nternational Journal of Scientific and Research Publications, Volume 4, Issue 12, December 2014

[10]. Emblemsvag, J. (2003). Life-cycle costing: using activity-based costing and Monte Carlo methods to manage future costs and risks. John wiley \& sons.

[11]. Hamdan, Khawla Hussein, Bachay, Imtithal Rashid, Flayyih, Hakeem Hammood \& Talab, Hassnain Raghib . (2018). Using Capital Budget and Sensitivity Analysis to Predict Future Cash Flows and Evaluate Investment Projects: Empirical Study at Iraqi Company for Production, Marketing and Meat and Field Crops. Journal of Engineering and Applied Sciences. (pp. 1-12). 
[12]. Hansen, D., Mowen, M., \& Guan, L. (2009). Cost management: accounting and control. Cengage Learning.

[13]. ICF \& EPA, United States. Environmental Protection Agency. Office of Pollution Prevention, \& ICF Incorporated. (1995). An introduction to environmental accounting as a business management tool: key concepts and terms. US Environmental Protection Agency, Office of Pollution Prevention and Toxics.

[14]. Ismail, M. S., Ramli, A., \& Darus, F. (2014). Environmental management accounting practices and Islamic corporate social responsibility compliance: evidence from ISO14001 companies. Procedia-Social and Behavioral Sciences, 145, 343-351.

[15]. Mreza, M.D, Bachay, I.R. \& Flayyih, H.H. (2018). The Role Higher Education Quality in Achieving Sustainable development: Field Study from the perspective of Iraqi Universities Instructors. The annual second conference

[16]. Papadakis, V. M., Lioukas, S., \& Chambers, D. (1998). Strategic decision-making processes: the role of management and context. Strategic management journal, 19(2), 115147.

[17]. Peterlin, J., Pearse, N. J., \& Dimovski, V. (2015). Strategic decision making for organizational sustainability: The implications of servant leadership and sustainable leadership approaches. Economic and Business Review for Central and South-Eastern Europe, 17(3), 273.

[18]. RAKOS, I. S., \& Antohe, A. (2014). Environmental Cost-An Environment Management Accounting Component. International Journal of Academic Research in Accounting, Finance and Management Sciences, 4(4), 166-175.

[19]. Sarkis, J. (2003). A strategic decision framework for green supply chain management. Journal of cleaner production, 11(4), 397-409.

[20]. Shapiro, K., Stoughton, M., Graff, R., \& Feng, L. (2000). Healthy hospitals: environmental improvements through environmental accounting. Boston, MA: Tellus Institute.

[21]. Stokman, F. N., Van Assen, M. A., Van der Knoop, J., \& Van Oosten, R. C. (2000). Strategic decision making. In Advances in Group processes (pp. 131-153). Emerald Group Publishing Limited.

[22]. Vasilescu, C. (2011). Effective strategic decision making. Journal of Defense Resources Management, 2(1), 101.

\section{Article history:}

- Received 31 July 2018

- Accepted 25 November 2018 